Joanna Kulawiak-Cyrankowska

\title{
TŁUMACZENIE NIEZBĘDNE? GARŚĆ UWAG NA TEMAT JĘZYKA ŁACIŃSKIEGO W ŚWIECIE POLSKIEJ ROMANISTYKI PRAWNICZEJ
}

\section{Is translation indispensable? Several remarks on the Latin language in the world of Roman law studies in Poland}

\begin{abstract}
The decline of Latin in Polish schools starts to affect the Academia as well. The author of this paper draws attention to the trend of translating the Roman legal sources in the body of papers published by Polish Romanist lawyers. This increasingly common practice seems to be indispensable if the authors want their readers, however belonging to the narrow group of Romanists, to follow their writing. On the one hand, Latin language skills are an essential part of research competences of a Romanist lawyer. On the other hand, however, there rises a risk that the researchers of Roman law soon will not be able to translate the legal sources on their own, which calls into question the quality of the study of Roman law in the near future.

Key words: Latin teaching, sources of Roman law, the Study of Roman law, translation of the sources, research into competences of a Romanist lawyer

Słowa kluczowe: nauczanie łaciny, źródła prawa rzymskiego, nauka prawa rzymskiego, tłumaczenie źródel, kompetencje badawcze romanisty
\end{abstract}

W 1902 r. Theodor Mommsen, wybitny znawca prawa rzymskiego, otrzymal Nagrodę Nobla w dziedzinie literatury za swoje dzieło pt. Römische Geschichte. Praca ta, po dziś dzień uważana za ważne źródło wiedzy na temat starożytnego Rzymu, została przetłumaczona na wiele języków, w tym także na język polski. Wyzwanie w postaci przekładu czterech tomów tego monumentalnego opracowania podjął Tomasz Dziekoński, tym samym na zawsze zaskarbiając sobie wdzięczność polskich historyków starożytników. Na początku przedmowy do tomu I, wydanego w roku 1867, Dziekoński pisze:

Historyą rzymską Mommsena odważam się przedstawić Czytelnikom. Oryginalny a nader trafny pogląd autora na dzieje panów świata, stał mi się pobudką 
do przedsięwzięcia tej pracy, i wlał we mnie to przekonanie, iż się przysłużę nieznającym języka oryginału, a pragnącym gruntownej nauki ${ }^{1}$.

Tłumacz w zaledwie paru słowach wyłożył główne przeznaczenie przekładu. W tym kontekście nie wydaje się szczególnie istotne, że Dziekoński pracował nad dziełem z połowy XIX wieku i przekładał z języka niemieckiego na język polski, bo powyższa deklaracja pozostaje nadal aktualna. Tłumaczenia bowiem dokonuje się przede wszystkim dla tych, którzy nie znają języka oryginału lub też nie władają w nim sposób wystarczający do zrozumienia treści źródła, a chcą się z nią zapoznać.

Powyższy wstęp, poczyniony być może nieco okrężną drogą, z powodzeniem naprowadza jednak na tematykę przekładów łacińskich ${ }^{2}$ źródeł prawnych. Obok kompleksowych wydań przekładów źródeł wraz z komentarzami ${ }^{3}$ uwagę zwraca zagadnienie przekładów niejako wpadkowych, a zatem tłumaczeń

1 T. Dziekoński, Przedmowa, [w:] T. Mommsen, Historya Rzymska, t. 1, przeł. T. Dziekoński, Drukarnia Józefa Ungra, Warszawa 1867, s. I.

2 Autorka celowo ogranicza rozważania do języka, który przez wieki stanowił fundament rei publicae litterarum. Inne języki antyczne skrzętnie pomija. W tym miejscu zostanie jednak uczyniony wyjątek. Niedawno na rynku wydawniczym ukazała się książka Anny Tarwackiej, będąca wynikiem poszukiwań odwołań do instytucji prawnych w zbiorze dowcipów Philogelos napisanym w języku greckim. W treści podziękowań Autorka, która z wykształcenia jest nie tylko prawnikiem, ale również filologiem klasycznym, wyznaje: „muszę dodać, że Profesor Kuryłowicz w sposób wyjątkowo przebiegły przekonał mnie do przetłumaczenia cytowanych w pracy tekstów źródłowych". Całe szczęście. Graeca sunt, non leguntur („Greki się nie czyta”). Zob. Obrócić prawo w żart. Instytucje prawne w zbiorze dowcipów „Philogelos”, Wydawnictwo Naukowe Uniwersytetu Kardynała Stefana Wyszyńskiego, Warszawa 2016, s. 7. (Średniowieczni uczeni w prawie twardo trzymali się przytoczonej powyżej zasady. Chcąc badać prawo rzymskie w jego najczystszej postaci, najczęściej bądź zupełnie pomijali greckie źródła, bądź nawet usuwali greckie fragmenty z tekstów łacińskich. Czy nie podobnie dzieje się dzisiaj z łaciną? Latina sunt ergo non leguntur?).

${ }^{3}$ W tym zakresie polscy badacze prawa rzymskiego prezentują z sukcesami coraz większe osiągnięcia. Chociaż nie sposób w tym miejscu przedstawić ogółu prac ostatnich lat, to na pewno należy podkreślić rangę polskiego przekładu wszystkich pięćdziesięciu ksiąg Digestów justyniańskich (zob. Digesta Iustiniani: Digesta Justyniańskie. Tekst i przekład, t. 1: księgi 1-4, red. T. Palmirski, Poligrafia Salezjańska, Kraków 2013, a także pozostałe tomy), Zbioru prawa Mojżeszowego i rzymskiego (zob. Zbiór prawa Mojżeszowego i rzymskiego (prawo Boskie, które Pan przekazat Mojzeszowi). Tekst łacińsko-polski, przeł. i objaśn. A. Dębiński, Wydawnictwo KUL, Lublin 2011), jak również Ustawy XII Tablic (zob. Ustawa XII Tablic. Tekst - tłumaczenie - objaśnienia, red. M. i J. Zabłoccy, Wydawnictwo Liber, Warszawa 2003). W tym samym duchu realizowana jest rubryka „Tłumaczenia - Monumenta aere perenniora” czasopisma „Zeszyty Prawnicze UKSW”. 
tekstów źródłowych zamieszczonych w treści publikacji obok samych źródeł. Jest to coraz częstsza praktyka w środowisku romanistów prawniczych (tj. badaczy zajmujących się prawem obowiązującym w starożytnym Rzymie, a także recepcją i nauką tego prawa). W literaturze obcojęzycznej, zwłaszcza anglojęzycznej, stała się ona standardem. Wydaje się jednak, że romanistyka prawnicza znajduje się obecnie w momencie, w którym tendencja ta przekuta została w konieczność.

Rola, jaką język łaciński odegrał w kształtowaniu się kultury prawnej, jest nieprzeceniona ${ }^{4}$. Niestety, w świecie prawniczym, który powinien stanowić ostoję łacińskiej tradycji, poziom znajomości łaciny prezentuje się naprawdę nieciekawie, a jej użyteczność (a to już mało kto przyzna otwarcie) coraz bardziej sprowadza się dzisiaj do roli ozdobnika ${ }^{5}$.Z pewnym zakłopotaniem trzeba przyznać, że prawnicy ochoczo prezentują postawę, którą można streścić w słowach ius, ius, ius - et nihil plus ${ }^{6}$.

Obecnie prawa w Polsce naucza się w dwudziestu pięciu szkołach wyższych. $\mathrm{Na}$ części wydziałów prawa języka łacińskiego dla prawników nie wykłada się wcale lub prawie wcale. Z kolei liderzy w tej klasyfikacji oferują lektoraty w wymiarze 60 godzin w ciągu roku akademickiego. Nauczanie odbywa się przy tym metodą przeznaczoną do zrealizowania w ciągu 1400-2000 godzin lekcyjnych. Właśnie taka, przyjęta w programach studiów uniwersyteckich analiza

${ }^{4}$ Jednym $\mathrm{z}$ bardziej efektownych, ale na pewno nie jedynym dowodem na to, jak głęboko zakorzeniona jest tradycja prawa rzymskiego we współczesnej myśli prawniczej, było opatrzenie kolumn gmachu Sądu Najwyższego w Warszawie inskrypcjami w postaci łacińskich paremii prawniczych wraz z ich tłumaczeniami. W skład zespołu, któremu powierzono opracowanie inskrypcji i którym kierował prof. dr hab. Witold Wołodkiewicz, wchodzili: dr Agnieszka Kacprzak, dr Jerzy Krzynówek oraz prof. dr hab. Maria Zabłocka. Na temat powyższego projektu powstała nawet stosowna monografia, w przedmowie do której prof. dr hab. Lech Gardocki napisał: „Czytając inskrypcje mamy poczucie ciągłości cywilizacyjnej, przypominamy sobie nasze związki z cywilizacją rzymską, z prawem rzymskim, a także z późniejszymi źródłami prawa, $\mathrm{w}$ dużym stopniu inspirowanymi rzymskimi wzorcami" (zob. Przedmowa, [w:] Regulae iuris. Łacińskie inskrypcje na kolumnach Sąu Najwyższego Rzeczpospolitej Polskiej, red. W. Wołodkiewicz, wyd. 3, C.H. Beck, Warszawa 2011, s. XI).

${ }^{5}$ Jak zawsze z humorem, ale również nie szczędząc Czytelnikowi gorzkich przemyśleń, aktualną analizę problemu przedstawia Maciej Jońca. Zob. tegoż Prawo rzymskie. Marginalia, wyd. 2, Lublin 2015, s. 326-341.

6 Trzeba zaznaczyć, że przywołane stwierdzenie przypisuje się filologowi klasycznemu Christophowi Cellariusowi, który tymi słowami zareagował na gwałtownie zwiększającą się wśród studentów popularność nauk prawniczych na Uniwersytecie w Halle (Salle). Rzeczywiście liczba zapisów na studia prawnicze w ciągu około stu lat (od początków XVIII wieku) wzrosła z 12\% do aż 75\%. Por. T. Ziolkowski, German Romanticism and Its Institutions, Princeton University Press, Princeton 1992, s. 71. 
strukturalno-leksykalna, nazywana metodą gramatyczno-tłumaczeniową, była źródłem gombrowiczowskich koszmarów. Silnie nastawiona na aspekt translatorski, niewątpliwie wspomaga rozwój kompetencji w języku, na który się tłumaczy. Trudno jednak za jej pomocą osiągnąć rezultat w postaci bezproblemowego rozumienia tekstu oryginalnego, należący przecież do jednego z głównych celów nauczania języków obcych nowożytnych. Umiejętności językowe na odpowiednim poziomie pozwalają na rozumienie źródła bez podejmowania wysiłku tłumaczenia go. Nie ma chyba wątpliwości, że do takich kompetencji językowych, pozwalających na bezpośrednie rozumienie tekstów oryginalnych, powinni dążyć romaniści prawniczy ${ }^{7}$. Badacz nie będzie przecież mógł zrozumieć kategorii, które służyły poprzednim pokoleniom, jeżeli najpierw nie pozna języka, którym owe generacje się posługiwały.

Warto się jednak zastanowić, czy w dobie, w której nie dbamy o klasyczne wykształcenie młodych ludzi ${ }^{8}$, autor publikacji naukowej z zakresu prawa rzymskiego może w ogóle oczekiwać od swojego potencjalnego odbiorcy znajomości łaciny. Z jednej strony wydaje się wątpliwe, by ktokolwiek spoza grona romanistów prawniczych, filologów klasycznych i historyków starożytników dogłębnie zapoznawał się z treścią specjalistycznych publikacji naukowych dotyczących prawa rzymskiego. Gremium odbiorców jest więc raczej hermetyczne. Można zatem przyjąć założenie, iż romaniści publikują dla osób o określonych zainteresowaniach naukowych i posiadających lub próbujących zdobyć odpowiedni

7 Trudno stwierdzić, czy jest możliwe opracowanie podręcznika dla adeptów prawa przeznaczonego do nauki języka łacińskiego, który byłby zgodny z wytyczną proponowaną przez Hansa Henninga Ørberga: legere, agere neque convertere umquam (czytać, działać, nic nie tłumaczyć). Z jednej strony w prawie występuje wiele pojęć abstrakcyjnych. Niełatwo sobie wyobrazić, jak można wytłumaczyć np. termin culpa (wina) bez jego przetłumaczenia. $Z$ drugiej jednak strony, chociaż Rzymianie nie pozostawili nam rozbudowanej teorii prawa, to przecież byli w stanie wyjaśniać oraz stosować pojęcia abstrakcyjne. Być może, gdyby spróbować porzucić współczesne teoretyczne myślenie prawnika „kontynentalnego" i korzystać jedynie z dorobku jurystów rzymskich, można by zaproponować publikację, która pozwoliłaby na wyeksponowanie treści samego źródła i pominięcie aspektu postrzegania prawniczego języka łacińskiego z perspektywy tak współczesnej nauki prawa, jak i języka polskiego w ogóle. Niewykluczone, że miałoby to również znakomity wplyw na poziom prowadzonych badań. Szerszą analizę wspomnianej metody podejmuje w swoim artykule Marcin Loch (zob. „Latine loquor!”- czyli „żywa łacina” jako metoda dydaktyczna, „Symbolae Philologorum Posnaniensium" 2015, t. 25, nr 2, s. 145-146).

${ }^{8}$ Od wielu lat obserwujemy powolny i systematyczny proces wypierania łaciny ze szkół i wydaje się, że właśnie osiąga on swoje apogeum. Na temat sytuacji w zakresie nauczania języka łacińskiego bardzo szeroko pisze Gościwit Malinowski (zob. Nauczanie języka łacińskiego w Polsce. Rys historyczny i stan obecny; https://www.academia. $\mathrm{edu} / 30959314)$. 
warsztat, by zgłębiać stosowne problemy badawcze. A stawiając sprawę zupełnie jasno, autor takiej publikacji powinien móc założyć, iż jego odbiorca będzie znał język łaciński. I nie chodzi o kompetencje językowe native speakera ${ }^{9}$, które pozwalają obywać się bez pomocy słowników i gramatyk, ale o taką, która pozwoli czytelnikowi po prostu zapoznać się, chociażby pobieżnie, z treścią źródła. Autor powinien móc oczekiwać, że język łaciński nie będzie dla jego odbiorcy na tyle obcy, iż pominie on całkowicie treść źródła i przejdzie od razu do jego komentarza. A jednak w dniach, w których jesteśmy świadkami zrywania więzi pomiędzy współczesnością a dziedzictwem całego zachodnioeuropejskiego kręgu kulturowego, chyba nie sposób już spodziewać się, że odbiorca samodzielnie podoła interpretacji wcześniej nieprzetłumaczonego tekstu.

W obliczu tak postawionego problemu narzuca się pytanie: co robić? Tłumaczyć czy nie? Czy przeciwstawić się powszechnym tendencjom, czy też uznać, że czasy się zmieniają i podążać coraz bardziej popularną drogą?

Badacz rezygnujący z tłumaczenia tekstów źródłowych być może nie ryzykuje możliwością, że jego publikacje będą pomijane, ale powinien się liczyć z możliwością, że oferowany przekaz będzie w pewnym stopniu zaburzony. Z kolei ten, który decyduje się na praktyki translatorskie, niekoniecznie kapituluje

9 Termin native speaker w kontekście nauczania języka łacińskiego z pewnością stanowi znaczne nadużycie. Warto jednak w tym miejscu zaznaczyć, że w Polsce coraz bardziej popularny staje się ruch tzw. łaciny żywej (Latinitas viva). Nie zagłębiając się w wątpliwości odnoszące się do poprawności tego określenia, należy zwrócić uwagę, iż także w Polsce (w Poznaniu i we Wrocławiu) istnieje możliwość uczestniczenia w kursach języka łacińskiego, w ramach których odbywają się zajęcia wyłącznie w języku łacińskim. Trzeba również podkreślić, że nie jest to inicjatywa przeznaczona tylko dla „wybranych”, a lekcje prowadzone są na różnych poziomach zaawansowania, także na tym podstawowym. Na temat samej metody dydaktycznej oraz jej znakomitych efektów zajmująco piszą Marcin Loch (zob. „Latine loquor!”..., s. 137-151) oraz K. Ochman (zob. Nauczanie łaciny. Immersja czy gramatyka?, "Języki Obce w Szkole” 2014, nr 3, s. 54-58). Chociaż dzisiaj pomysł immersyjnego kursu języka łacińskiego może wydawać się dość egzotyczny, jeszcze bez mała sto lat temu mówienie po łacinie w środowisku ludzi wykształconych w żadnym razie nie uchodziło za eksces. Filolog klasyczny Jerzy Axer, wspominając swojego nauczyciela Kazimierza Kumanieckiego, pisał: „Mówienie po łacinie na konferencjach naukowych (a nawet traktowanie jej jako języka wykładowego) było jeszcze w latach młodości Profesora czymś naturalnym, dopiero po II wojnie światowej zaczęło szybko zanikać. Rzecz więc nie w tym, że Kumaniecki po łacinie mówił [...]. Istotę fenomenu, który próbuję opisać, stanowi odmienność łacińskiego krasomówstwa Profesora od tej powszedniej techniki przemawiania po łacinie, którą opanował każdy niemal dobry latynista jego pokolenia”. Zob. J. Axer, Kazimierz Kumaniecki 1905-1977, [w:] W kręgu wielkich humanistów. Kultura antyczna w Uniwersytecie Warszawskim po I wojnie światowej, red. I. Bieżuńska-Małowist, Państwowe Wydawnictwo Naukowe, Warszawa 1991, s. 100. 
wobec wspomnianych wcześniej niebezpiecznych tendencji. Musi jednak być świadom, iż każdy przekład niesie ze sobą pewne znamiona interpretacyjne. Nie zastąpi więc analizy tekstu oryginalnego. Lektura samego tłumaczenia ogranicza zatem w znacznym stopniu dyskusję naukową.

Gdyby nie okoliczności sprawiające, że tytułowe „tłumaczenie niezbędne" to tak naprawdę przekład poczyniony po to, by nadawca - autor publikacji naukowej mógł komunikować się ze swoim odbiorcą, prawdopodobnie warto byłoby sugerować powszechne stosowanie tego typu praktyk i, tym samym, doskonalenie umiejętności translatorskich. Tłumaczenia mogą przecież bardzo pozytywnie wpływać na poziom rozważań. Rzetelny przekład jest najlepszym dowodem na to, że jego autor pojął treść źródła. Powinna to być jednak dobrowolna decyzja, a nie przymus warunkowany stanem niewiedzy potencjalnego odbiorcy. Skoro jednak nie dbamy o to, by nauczano języka łacińskiego na wcześniejszych, jeszcze przedakademickich stadiach edukacji, to - w konsekwencji - nie możemy się wiele spodziewać po językowych kompetencjach czytelnika dopiero rozpoczynającego swoją drogę naukową.

Założenie, że opisywany tutaj problem dotyczy jedynie wąskiego grona filologów klasycznych jest tak naprawdę zamiataniem go pod dywan. Badacz prawa rzymskiego, poza stosownym warsztatem prawniczym, musi rzecz jasna zdobyć kompetencje z wielu dyscyplin, w tym z zakresu języka łacińskiego, które zapewnią mu samodzielność i niezależność naukowej refleksji. Skoro znajomość łaciny stanowi fundamentalny element warsztatu naukowego badacza prawa rzymskiego, należy się zastanowić, co czeka romanistów prawniczych porzucających dziedzictwo, którym jest szeroko pojęta latinitas, a której romanitas jest przecież częścią.

Niepodjęcie stosownych kroków na polu naukowym najpewniej doprowadzi do zupełnego odcięcia się od oryginalnych źródeł i korzystania wyłącznie z tłumaczeń. Można znaleźć publikacje obcojęzyczne z lat 80 . XX wieku, których autorzy bądź w treści tekstu głównego od razu zamieszczają tłumaczenie, źródło przywołując jedynie w przypisie, bądź w ogóle rezygnują z przytoczenia oryginalnego tekstu ${ }^{10}$. Warto sobie uświadomić, że odcinając się od łaciny, odrzucamy przestrzenie badawcze rozwijające się przez ponad dwa tysiące lat. Pytanie o jakość nauki w najbliższych dziesięcioleciach budzi co najmniej niepokój, gdy wiele wskazuje na to, że badacze będą w stanie operować jedynie na tekstach przetłumaczonych, podczas gdy na bibliotecznych półkach nadal leżą tomy czekające na odkrycie i dogłębną analizę ${ }^{11}$.

10 Celem niniejszej publikacji jest jedynie zwrócenie uwagi na pewne praktyki w ogólnym ujęciu, a nie recenzowanie poszczególnych publikacji pod względem ich poprawności warsztatowej. Trzeba mieć nadzieję, że samo ukazanie problemu wystarczy, by zahamować wspomniane niepokojące procesy.

11 Jürgen Leonhardt podaje w tym zakresie nadzwyczajne statystyki. Według niego cała spuścizna literacka epoki starożytnej (okresu pogańskiego i wczesnochrześcijańskiego), 
Szczęśliwie, badacze prawa rzymskiego nie muszą jeszcze porzucać wszelkiej nadziei. Alternatywne sposoby nauczania łaciny coraz odważniej wybijają się na niepodległość. Nauczyciele akademiccy wykładający język łaciński dla prawników powinni tę dyskusję nie tylko śledzić i czerpać z niej, ale również w niej uczestniczyć. Odpowiednia stymulacja ze strony środowiska akademickiego i atrakcyjna oferta edukacyjna, czy też programy doskonalące warsztat językowy, mogłyby odwrócić zasygnalizowany tutaj proces i zaowocować rezultatami badawczymi o randze międzynarodowej. Tradycja klasyczna to przecież dziedzictwo, w którego atrakcyjność nie sposób zwątpić, zaznawszy go chociaż raz. Należy jedynie zadbać o to, by oferowano je w formie na miarę naszych czasów ${ }^{12}$.

\section{Bibliografia}

Axer J., Kazimierz Kumaniecki 1905-1977, [w:] W kręgu wielkich humanistów. Kultura antyczna w Uniwersytecie Warszawskim po I wojnie światowej, red. I. Bieżuńska-Malowist, Państwowe Wydawnictwo Naukowe, Warszawa 1991, s. 90-113.

Digesta Iustiniani: Digesta Justyniańskie. Tekst i przekład, t. 1: księgi 1-4, red. T. Palmirski, Poligrafia Salezjańska, Kraków 2013.

Jońca M., Prawo rzymskie. Marginalia, wyd. 2, Wydawnictwo KUL, Lublin 2015.

Leonhardt J., Latein. Geschichte einer Weltsprache, C.H. Beck, München 2009.

Loch M., „Latine loquor!”- czyli „żywa tacina” jako metoda dydaktyczna, „Symbolae Philologorum Posnaniensium" 2015, t. 25, nr 2, s. 137-151.

Mommsen T., Historya Rzymska, t. 1, przeł. T. Dziekoński, Drukarnia Józefa Ungra, Warszawa 1867.

Ochman K., Nauczanie łaciny. Immersja czy gramatyka?, „Języki Obce w Szkole” 2014, nr 3, s. 54-58.

Ochman K., Zmierzch cywilizacji łacińskiej czy początek szóstego renesansu?, „Nauka” 2017, nr 4, s. 129-140.

Regulae iuris. Łacińskie inskrypcje na kolumnach Sądu Najwyższego Rzeczpospolitej Polskiej, red. W. Wołodkiewicz, wyd. 3, C.H. Beck, Warszawa 2011.

którą można by zawrzeć $\mathrm{w}$ około pięciuset pięćsetstronicowych współczesnych tomach, wydaje się być tak naprawdę tylko kroplą w morzu lacińskiego dziedzictwa, szacowanego objętościowo na około pięć milionów woluminów tych samych rozmiarów. Por. Latein. Geschichte einer Weltsprache, C.H. Beck, München 2009, s. 2-3.

${ }^{12}$ Tradycja i nowoczesność nie muszą przecież wzajemnie się wykluczać. Niezawodna Katarzyna Ochman, chociaż nie szczędzi krytycznych refleksji, wlewa mnóstwo otuchy w serca miłośników kultury klasycznej. Zob. koniecznie Zmierzch cywilizacji tacińskiej czy początek szóstego renesansu?, „Nauka” 2017, nr 4, s. 129-140 (ze szczególnym uwzględnieniem s. 138-139). 
Tarwacka A., Obrócić prawo w żart. Instytucje prawne w zbiorze dowcipów „Philogelos”, Wydawnictwo Naukowe Uniwersytetu Kardynała Stefana Wyszyńskiego, Warszawa 2016.

Ustawa XII Tablic. Tekst - tłumaczenie - objaśnienia, red. M. i J. Zabłoccy, Wydawnictwo Liber, Warszawa 2003.

Zbiór prawa Mojżeszowego i rzymskiego (prawo Boskie, które Pan przekazał Mojżeszowi). Tekst łacińsko-polski, przeł. i objaśn. A. Dębiński, Wydawnictwo KUL, Lublin 2011.

Ziolkowski T., German Romanticism and Its Institutions, Princeton University Press, Princeton 1992.

\section{Netografia}

www.academia.edu/30959314 (dostęp: 11.12.2017).

www.polka1.pl/artykuly/lacina-na-skraju-1 (dostęp: 11.12.2017). 